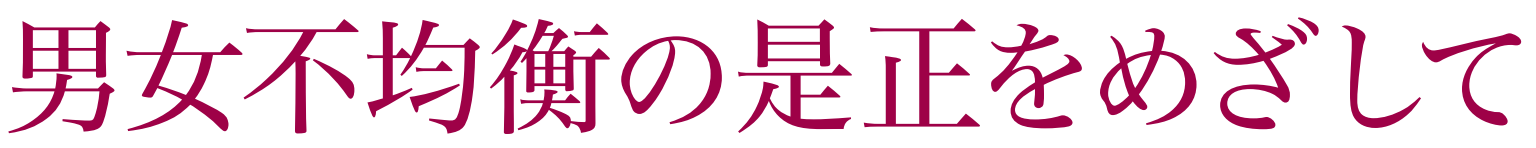

\title{
Starting at the top
}

\author{
Nature Vol.447 (115-116)/10 May 2007
}

エリート科学者間でなお続く、極端な男女の不均衡状態を是正するための取り組みについて、考えていく べき時である。

5 月 1 日に米国の国立科学アカデミーの新会員に選ばれた 72 人のリストの中で、9人の女性科学者の名前（Tania Baker、 Ursula Bellugi、Karen Cook、Mary Estes、Pamela Fraker、 Angela Gronenborn、Helen Hobbs、Laura Kiessling、 Eve Marder）が光彩を放っている。

しかし、2 年前には 19 人の女性が新会員に選ばれたのに対 し、今回はその半数にも満たなかった。科学の世界に女性を 送り込むためのプログラムは、すでに長年にわたって多数実 施されてきた。女性科学者が出産や育児を経ながらもキャリ アを継続できるよう支援する措置も、折々で実施されている。 しかし、シニアレベルでみられる男女の不均衡は、是正という にはほど遠い状態である。

もちろん、エリート科学者の地位に登りつめる女性もいる。科 学アカデミーは4 月29日の会議で、最高の栄誉である『Public Welfare Medal』を生物学者の Maxine Singerに授与した。だが、 科学者ヒエラルヒーの頂点に立つ女性はほとんどいないのが現状だ。

科学アカデミーに属する女性会員の割合は、全体の約 10 パー セント。わずか 6 パーセントだった 2000 年から考光ると、そ の割合は増加してはいるものの、それでもな打失望させられ る数字である。また、多くの研究領域で女性科学者の数が増 えてきてはいるが、エリート科学者の仲間入りは今でもむず かしいとされる。女性の地位向上の歴史が最も長い米国でも、 この状況は変わっていない。

米国科学界で最も格式の高いクラブである科学アカデミーの 会員は、ほとんどが特定の年齢層の白人男性である。このこ とはアカデミー自体も十分に認識しており、この点を改善す るための試みは何度もなされてきた。だが、科学アカデミー の新会員は、ほかの会員による推薦を得てから選出されるこ とになっているため、当然のことながら、この仕組みそのも のが、会員構成の偏りを永続させる原因となっている。これ に対して、研究分野ごとに設けられている科学アカデミー 31 部門のうちの一部では、有望な女性会員候補を見つけ出すた めに、より積極的な方法を採用している。例えば、2003年に は (既会員の推薦以外にも) 独自の候補者指名リストが作られ、 より多くの女性や若手の科学者が会員候補として挙げられる ようになった。また、ロンドンの英国学士院も同様の活動を 通じて、過去 5 年の間に女性会員の数を増やしている。

このような施策は称賛されるべきだが、期待されたほど機能 していないようにも思われる。ただ、これより直接的に問題解
決に取り組む方法には問題がある。例えば、女性会員を増やす ために何らかの定数を導入するとなれば、定数制（いわゆる「女 性枠」にによって選ばれた女性会員の地位が軽んじられる抢そ れがあり、これを引き金とした連鎖的な問題発生が予想される。 毎年選ばれる新会員数自体の上限を若干引き上げる、という のはどうだろうか。そうすれば、科学界の規模拡大と学術的多 様性をよりよく反映し、男女を問わず、推挙に值する科学者に 対してわずかでも道を広げられるかもしれない。ただし、この方 策では男女の不均衡を解消する効果は、ほとんど期待できない。

科学アカデミーが取りうる最善の方法は、拀そらく、部門 ごとに相応の資格を有する女性を確実に候補者リス卜に載せ ることができるような、何らかの方法を考案することだろう。 そうした変革を確かなものにするには、例えば、多様なバッ クグラウンドをもつ候補者をリストに載せることを義務づける 規定などが必要になってくるかもしれない。

科学アカデミーの各レベルの会員たちは、女性科学者に対す る公平な待遇が確保されるよう、より積極的で公然とした役 割を果たしていくべきである。科学界に打ける女性、あるい は少数派の人々の地位向上に関する議論は、たいていの場合、 当事者（通常は女性、または少数派の人々自身）の間から起 こってくる。指導的な地位に立つ人々が参加することもある が、多様性の拡大を単なる心地よい活動（平等という美名の もとになされた善行として歴史に記録され、その後は忘れら れてしまうだけの活動）にとどまらせないで拈けるかどうか は、そうしたトップに立つ彼らの認識にかかっている。

米国の物理学界に扔ける新たな行動は、この方向への前進 として称賛さ机るべきだろう。2007年5月 6 〜 8 日、米国内 の国立研究所の物理学部長 50 人とシニアマネージャー 15 人が メリーランド州カレッジパークに集まり、2022年までに女性の 物理学者を倍増させる方法について議論した。ハイレベルな研 究者が数多く出席したことは、楽観材料である。今後この活 動がぞのように展開していくかはまだ不透明だが、ほかの研 究分野に抏いても似たような行動が検討されていってほしい。

米国の女性が科学界の頂上に登りつめるには、下から始め なければならないとこれまで何十年にもわたっていわれてき た。しかし、この状況はあまりにも長い間、続いてきている。 すでにエリート科学者となった人々は、自らの置かれた地位 をふまえて、いまこそ上から、男女間の正真正銘の公平を実 現するための責任を負わなければならない。 